\title{
Pemanfaatan GPS Sebagai Sarana Mendapatkan Pertolongan Ketika dalam Kondisi Bahaya dengan Algoritma Divide and Conquer untuk Menentukan Lokasi Terdekat
}

\author{
Dyas Yudi Priyanggodo \\ Program Studi Informatika \\ Fakultas Teknik Universitas Muhammadiyah Tangerang \\ Jl. Perintis Kemerdekaan 1/33 Cikokol Kota Tangerang TLP. 55793251 \\ priyanggodo.15@gmail.com
}

\begin{abstract}
Abstrak - Semakin pesatnya teknologi perangkat mobile berbasis android yang sudah dilengkapi berbagai jenis sensor sebagai fitur yang disediakan vendor untuk dapat memenuhi kebutuhan para pengguna smartphone-nya. Beberapa sensor yang terdapat pada smartphone adalah Accelerometer, Gyroscope, Magnetometer, Light Sensor, Touch screen, GPS, WiFi, GSM Cell, NFC, Camera front, Camera back, dan Proximity. Dari banyaknya sensor-sensor yang terdapat pada smartphone tersebut salah satu yang populer adalah GPS. Pengguna yang menggunakan aplikasi yang memanfaatkan fitur GPS pada smartphone-nya dapat mengetahui posisinya dan juga dapat mengetahui posisi pengguna lain yang terhubung dengan aplikasi tersebut, misalnya aplikasi Google Map. Sesuai gunaan fitur GPS yang dapat mengetahui posisi lokasi penggunanya dan pengguna lain. Fitur GPS dapat digunakan pada aplikasi penyelamatan diri dari tindak kejahatan dengan mengirimkan lokasi posisi pengguna yang sedang terancam kepada pengguna lain yang berada pada tempat terdekat atau dapat juga mengirimkan lokasinya pada pihak keamanan untuk dapat cepat mendapatkan pertolongan. Selain fitur GPS, aplikasi penyelamatan diri dari tindak kriminal ini juga harus dapat diakses secara cepat. Dengan adanya aplikasi tombol darurat, GPS juga dapat dimanfaatkan sebagai sarana memperoleh pertolongan jika dalam kondisi bahaya dan juga dapat mencegah terjadinya kejahatan. Hal ini juga dapat diartikan bahwa perkembangan teknologi ternyata juga dapat ikut serta dalam menjaga keamanan di dunia.
\end{abstract}

Kata Kunci: Android, Divide and Conquer, GPS.

Abstract - The more rapid technology based android mobile devices that have been equipped with various types of sensors as a feature provided by the vendor to meet the needs of its smartphone users. Some of the sensors contained in the smartphone is Accelerometer, Gyroscope, Magnetometer, Light Sensor, Touch screen, GPS, WiFi, GSM Cell, NFC, Camera front, Camera back, and Proximity. Of the many sensors contained in the smartphone is one of the popular GPS is. Users who use apps that take advantage of GPS features on their smartphones can find out their position and can also find out where other users are connected to the app, such as the Google Map app. Appropriate use of GPS features that can know the position of the location of its users and other users. The GPS feature can be used in self-sustaining applications of crime by sending the user's position location under threat to other users who are nearby or may also send their location to the security authorities in order to quickly get help. In addition to GPS features, self-saving applications from this criminal act must also be accessible quickly. With the emergency button application, GPS can also be used as a means of obtaining help if under hazard conditions and also can prevent the occurrence of crime. It can also be interpreted that the development of technology was also able to participate in maintaining security in the world.

Keywords: Android, Divide and Conquer, GPS. 


\section{PENDAHULUAN}

Perkembangan teknologi di era globalisasi saat ini semakin pesat, sehingga semakin menuntut setiap masyarakat dunia untuk mengikuti perkembangan teknologi. Salah satu teknologi yang berkembang dengan sangat pesat adalah teknologi pada telepon genggam atau yang biasa kita sebut dengan handphone/mobile phone. Awalnya fungsi handphone hanyalah sebatas sarana berkomunikasi antara satu orang dengan orang lain dimana saja dan kapan saja karena perangkat handphone bersifat portable, yang artinya mudah dibawa kemana saja.

Smartphone pada masa kini umumnya memiliki fungsi-fungsi seperti call, video call, pengiriman pesan berupa teks dan unsur multimedia (suara, gambar dan video), akses internet, pemutar file audio dan video, kamera pengambil gambar foto dan video, editor file multimedia (teks dan gambar), selain itu smartphone juga di lengkapi berbagai jenis sensor diantaranya accelerometer,

Gyroscope, magnetometer, Light Sensor, Touch screen, GPS, WiFi, GSM Cell, NFC, Camera front, Camera back, Proximity. Android merupakan salah satu sistem operasi perangkat mobile yang tergolong masih baru dan sangat berkembang. Android bersifat open source dan pertama kali di rilis oleh Google pada tahun 2009 dan sejak saat itu Sistem Operasi Android terus berkembang dengan pesat dan berhasil mendapatkan perhatian dari jutaan mobile phone user dan mobile developer. Hingga saat ini telah banyak vendor dari perangkat mobile yang telah menggunakan Sistem Operasi Android pada produk-produk mereka. Untuk memenuhi kebutuhan pengembangan, Google bersama dengan OHA merilis paket Android SDK (Software Development Kit) dan ADT (Android Development Tools) untuk mengembangkan aplikasi Android pada perangkat mobile. Android SDK sendiri terdiri dari sistem operasi, middleware dan aplikasi utama untuk perangkat mobile. Bahasa pemrograman yang digunakan pada Android adalah bahasa pemrograman Java yang telah diberikan fungsi-fungsi khusus untuk pengembangan Android sendiri. Dengan Android SDK dan ADT, developer bisa bebas berkreasi dalam menciptakan aplikasi-aplikasi yang nantinya bisa dipasarkan dan digunakan oleh banyak Android user.

Terlepas dari perkembangan teknologi smartphone, di dunia nyata tingkat kejahatan juga meningkat. Jenis-jenis kejahatan yang semakin bervariasi, misalnya saja perampasan sepeda motor yang populer disebut begal, penodongan, perampokan, penganiayaan, sampai pembunuhan. Menurut Statistik Kriminal 2014 yang diterbitkan oleh Badan Pusat Statistik Negara pada tahun 2013 tercatat 342.084 tidak pidana kejahatan dengan angka kejahatan per 100.000 penduduk 140, meningkat dari tahun 2012 tercatat 341.084 dengan angka kejahatan per 100.000 penduduk 134. Kejahatan-kejahatan tersebut banyak terjadi bukan hanya karena niat pelakunya, bisa saja karena adanya kesempatan. Misalnya saja kejahatan begal motor terjadi pada saat pengendara sendiri melewati tempat yang sepi. Tidak sempatnya korban memberi tahu teman yang terdekat dengan lokasi atau petugas keamanan semakin memperparah kejadian kejahatan tersebut. Karena pada saat dalam keadaan bahaya telpon maupun sms dirasa tidak efektif.

Dari fakta kejahatan diatas, dapat diberikan solusi dengan menggunakan smartphone khususnya menggunakan fitur GPS. Dapat dirancang sebuah aplikasi yang mudah diakses untuk dapat dengan cepat mengirimkan pesan permintaan tolong kepada orang terdekat (pengguna lain dengan aplikasi yang sama) dan juga petugas keamanan dengan mengirimkan koordinat lokasi terjadinya kejahatan dengan realtime. Sehingga dapat meminimalisir dampak dari kejahatan, bahkan dapat mencegah tindak kejahatan.

Di Kota Bandung juga telah dikembangkan aplikasi android yang serupa yaitu aplikasi tombol panik untuk cepat mendapatkan bantuan. Sesuai berita yang dilangsir oleh detik.com /12 Maret 2015, Walikota Bandung Ridwan Kamil memaparkan bahwa konsep dari aplikasi Tombol Panik yang sedang dikembangkan kota Bandung adalah aplikasi yang berisi satu tombol, jika tombol tersebut ditekan tiga kali aplikasi ini akan mengirimkan posisi koordinat pengguna aplikasi yang terancam kekeluarga yang sebelumnya sudah di daftarkan pengguna pada aplikasi, dan juga koordinat posisi tersebut dikirimkan pada Comman Center yang selanjutnya comman center menghubungi petugas terdekat dari posisi pengguna aplikasi yang terancam untuk melakukan tindakan.

Aplikasi Tombol Panik yang dikembangkan di Kota Bandung hanya kusus digunakan oleh warga bandung saja karena terhubung dengan Comman Center Kota Bandung. Untuk itu perlu dikembangkan lagi sebuah aplikasi yang 
bersifat universal dan dapat dipakai oleh siapa saja dan dimana saja.

\section{METODOLOGI DAN RANCANGAN PENELITIAN}

3.1 Metodologi Penelitian

Dalam penelitian ini digunakan metode studi pustaka yang dilakukan dengan cara mengumpulkan literatur dan referensi yang berhubungan dengan algoritma kriptografi Blowfish dan metode penukaran kunci Diffie Helman. Selain itu peneliti juga mengumpulkan literature dan referensi yang berhubungan dengan pengembangan aplikasi Android. Referensi atau data-data yang telah terkumpul disortir sesuai dengan bidang pembahasan mengenai algoritma Algoritma Divide and Conquer yang akan digunakan untuk mengenkripsi data laporan dalam aplikasi pada saat mengolah data.

\section{ARSITEKTUR SISTEM}

Sistem baru yang dibuat akan menghasilkan suatu informasi tentang lokasi pengguna aplikasi yang menekan tombol darurat. Penerima informasi adalah beberapa pengguna aplikasi lain yang terdekat dan pihak keamanan yang terdekat.

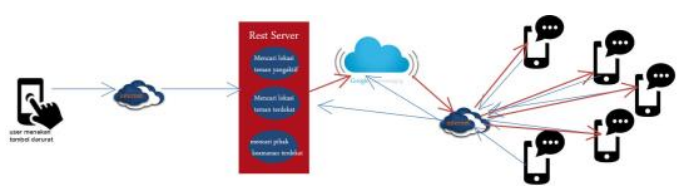

Gambar 1

Aplikasi yang dibuat ada dua macam, aplikasi server dan aplikasi mobile. Aplikasi server berupa web server. Aplikasi mobile berupa aplikasi yang digunakan melalui handphone berbasis Android. Input yang diminta sistem adalah lokasi asal pengguna saat menekan tombol darurat. Detail dari proses yang ada pada sistem dijabarkan sebagai berikut :

\section{Proses Penerimaan Permintaan}

Tahap pertama yang dilakukan oleh server untuk mendapatkan lokasi

semua pengguna aplikasi. Proses ini akan dijalankan pada saat server mendapat request, sehingga juga didapatkan user mana saja yang aktif. Proses request dilakukan oleh user dengan menggunakan aplikasi mobile. Pada saat request sampai pada server, server akan melakukan proses pengambilan detail data yan diperlukan untuk proses selanjutnya. Data-data yang diambil adalah posisi asal pengguna berupa latitude / longitude.
Pada saat melakukan request kepada server, inputan yang dikirimkan oleh aplikasi mobile berupa parameter-parameter. Parameterparameter yang diterima oleh server ini digunakan untuk mendapatkan jenis data yang diperlukan sebagai inputan. Jenis inputan yang diinginkan adalah posisi user.Hasil inputan ini akan digunakan untuk menjalankan proses selanjutnya.

2. Proses Pencarian Pengguna Lain Terdekat

Proses yang terjadi setelah penerimaan request dari user adalah melakukan

pencarian lokasi user lain. Lokasi user lain yang dicari adalah lokasi yang ada dekat dengan posisi user. Pada proses ini server akan menggunakan inputan data posisi user. Posisi user digunakan sebagai parameter untuk menentukan apakah lokasi dari user lain yang dicari user ada pada jarak yang dekat atau pada jarak yang jauh. Posisi user yang akan digunakan dalam proses pencarian berupa koordinat latitude dan longitude. Jika user menggunakan fasilitas GPS pada handphone, maka posisi user yang dikirimkan pada server berupa latitude dan longitude.

Proses pengiriman koordinat user kepada user lain menggunakan fasilitas Google Cloud Messaging (GCM). Google Cloud Messaging adalah layanan gratis yang membantu pengembang mengirimkan data dari server ke aplikasi Android. Ini dapat berupa pesan ringan yang dapat memberi tahu aplikasi Android bahwa ada data baru yang harus diambil dari server (misalnya, film yang diunggah oleh teman), atau berupa pesan berisi 4 KB muatan data (agar aplikasi seperti perpesanan instan dapat langsung diterima).

3. Proses Pencarian Lokasi pengguna terdekat dengan Algoritma Divide and Conquer

Jika diasumsikan pengguna aplikasi adalah titik pertama makan titik-titik yang lain adalah pengguna aplikasi lain.

Asumsi : $\mathrm{n}=2 \mathrm{k}$ dan

titik-titik diurut

berdasarkan absis $(\mathrm{x})$.

Algoritma Closest Pair :

SOLVE : jika $n=2$, maka jarak kedua titik dihitung langsung dengan rumus Euclidean. 
DIVIDE : Bagi titik-titik itu ke dalam dua bagian, PLeft dan PRight, setiap bagian mempunyai jumlah titik yang sama

CONQUER :Secara rekursif, terapkan algoritma $\mathrm{D}$-and-C pada masingmasing bagian. Pasaingan titik yang jaraknya terdekat ada tiga kemungkinan letaknya : Pasangan titik terdekat terdapat di bagian PLeft.

Pasangan titik terdekat terdapat di bagian PRight.

Pasangan titik terdekat dipisahkan oleh garis batas L, yaitu satu titik di PLeft dan satu titik di PRight. Jika kasusnya adalah (c), maka lakukan tahap COMBINE untuk mendapatkan jarak dua titik terdekat sebagai solusi persoalan semula.

\section{KESIMPULAN}

Kemampuan GPS untuk menunjukkan koordinat yang bereferensi global secara cepat dan relatif murah sangat membantu pembangunan data dan informasi spasial. Peran GPS sangat luas mulai dari ikut serta mendefinisikan sistem kerangka global (ITRF), merapatkan kerangka global ke sekala regional, nasional, bahkan lokal, sampai pada "mendigitasi" data lapangan secara realtime. Walapun tetap harus diperhatikan pada ruang georeferensi yang mana data atau informasi spasial tersebut akan "diikatkan" karena akan mempengaruhi pemilihan peralatan, metoda pengamatan dan metoda hitungan.

Dengan adanya aplikasi tombol darurat, GPS juga dapat dimanfaatkan sebagai sarana memperoleh pertolongan jika dalam kondisi bahaya dan juga dapat mencegah terjadinya kejahatan. Hal ini juga dapat diartikan bahwa perkembangan teknologi ternyata juga dapat ikut serta dalam menjaga keamanan di dunia.

\section{Daftar Pustaka}

[1] Esther Irawati S. , Gunawan, Indra Maryati, Joan Santoso, Rossy P.C.2012.

[2] PENCARIAN LOKASI FASILITAS UMUM TERDEKAT DILENGKAPI DENGAN RUTE KENDARAAN UMUM

LYN.Surabaya: Semantik

Gandarpurnama, B. (2015). Ridwan Kamil Siapkan 'Tombol Panik' untuk Kondisi

Darurat.[Online]. Tersedia

:http://inet.detik.com/read/2015/03/12/141707/2 856934/398/ridwan-kamil-siapkan-tombolpanik-untuk-kondisi-darurat
[3] Google Cloud Messaging for Android.Tersedia:

https://developer.android.com/google/gcm/i ndex.html

[4] Setiaji, Bambang.2006. PEMANFAATAN TEKNOLOGI GLOBAL POSITIONING

[5] SYSTEM (GPS) DALAM PEMBANGUNGAN INFORMASI SPASIAL.Surabaya: T. Geomatika ITS

[6] Sub Direktorat Statistik Politik dan Keamanan.2014.Statistik Kriminal 2014.Jakarta: Badan Statistik Negara 